\title{
THE SIGNIFICANCE OF SOIL MICROORGANISMS AS A LIMI- TING FACTOR IN INFECTION OF CLOVER BY SCLEROTINIA TRIFOLIORUM ERIKSS. AT DIFFERENT TIMES OF THE YEAR
}

\author{
Anna-Marja Halkilahti \\ Department of Plant Pathology, University of Helsinki
}

Received May 27, 1964

Antibiotic microorganisms limiting the growth of fungi are found very frequently in the soil $(4,5,27)$. Some of these microorganisms are also presumed to restrict the mycelial growth in the soil of the causal agent of clover rot (Sclerotinia trifoliorum ERIKSS.) (9, 21). Microbes with such an antibiotical effect on artificial culture media have been isolated from various parts of Finland $(21,22,23,24)$. It was observed during these studies that environmental factors, such as temperature and the quality of the growth medium, have a marked effect on the antibiotical capacity of the microbes $(10,22)$. The present paper describes investigations on the antagonistic effectivity of the soil - due to microorganisms (cf. PoHJaKallio, 20) - on the extent of clover rot infection in the soil. The principal object of these studies was the variation in the antagonistic effectivity of the soil at different times of the year. A second point investigated was the effect of the numbers of living microbes in the soil on clover rot infection.

\section{Experimental methods}

The trials were begun each year in April and continued until November or December. During this time, when the ground was not covered by snow, soil samples were taken about once a week from cultivated land. The samples were put in sterilized petri dishes $(\varnothing 9 \mathrm{~cm}) ; 5$ dishes per sample were used in 1961 and 6 in the other years. In addition, soil from each sample was autoclaved and put into 3 petri dishes. The soil was moistened with sterilized water. Mycelia of S. trifoliorum were transferred to the surface of the soil in the centre of the dish. Observations were subsequently made on the spreading of the mycelia on the soil surface. Since the mycelia of the clover rot fungus are often invisible to the naked eye, clover seed was sown in each dish so that the antagonistic capacity of the soil could be determined on 


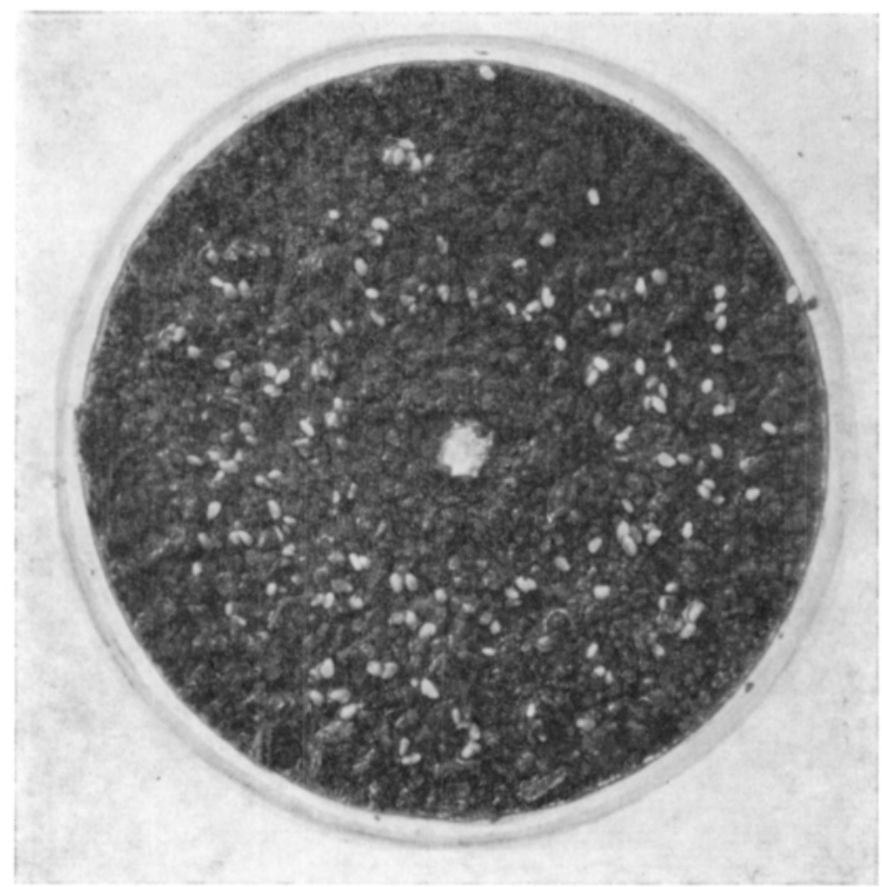

Fig. 1. The growth of S. trifolior u m mycelia in the soil samples was determined by sowing clower in the petri dishes; the smallest distance from the seeds to the transferred mycelia in the centre of the dish was $1.2 \mathrm{~cm}$.

the extent of the infection of the clover seedlings. Just before seeding, the seed was dressed with a solution of Ceresan and carefully rinsed with sterilized water. In sowing the nearest seeds were located at least $1.2 \mathrm{~cm}$ from the transferred mycelium of S. trifoliorum (Fig. 1).

In the years $1957-61$ the petri dishes were kept in a $\mathrm{thermos}$ a $\mathrm{t}$ at a temperature of $7-10^{\circ} \mathrm{C}$ and in $1961-63$ they were kept o u t d o or s in a shaded place. Accordinlyg, within one year (1961) similar trials were carried out both in the thermostat and outdoors.

The extent of in f e c t i o n of the clover seedlings by S. trifoliorum was evaluated after the two-week test period. If the fungus had infected the seedlings this was evidently caused by a reduction in the antagonistic effectivity of the soil. If the fungus did not produce infection, this was held to indicate an increased antagonistic capacity of the soil. In the tables showing the results of the trials, the percentages of the petri dishes in which the clover seedlings were infected by clover rot are indicated.

Soil s a mples were taken from a depth of $0-5 \mathrm{~cm}$ from the following fields: a) fallow, b) limed fallow, c) winter rye, d) soil where clover has been sown (with spring wheat as nurse crop) in the year of the test, as well as soil where clover had been sown in the previous year, e) unlimed area, and f) limed area. The main soil type was sandy clay with a $\mathrm{pH}$ of $5,5-6,0$. Ground limestone was applied to the 
surface layer of the soil $(0-10 \mathrm{~cm})$ in the spring before the commencement of the trials. In 1962 an amount of $12000 \mathrm{~kg} / \mathrm{ha}$ was applied, with the result that the soil became alkaline. In the following year, 1963, only $6000 \mathrm{~kg} /$ ha were used. In 1962 the $\mathrm{pH}$ of the fallow was $5.4-5.8$, that of the limed fallow $7.3-8.0$ and that of the clover field $6.0-6.5$. In 1963 the $\mathrm{pH}$ values were: fallow $5.1-5.5$, limed fallow $6.2-$ 7.0, clover field 5.6-6.3 and limed clover field $6.3-7.5$. The $\mathrm{pH}$ of the soil samples was not determined in the other years.

M y c e li a of $S$. trifoliorum for the trials were cultured at a temperature of $7-10^{\circ} \mathrm{C}$ on Henneberg agar (dist. water $100 \mathrm{ml}$, glucose $10 \mathrm{~g}, \mathrm{CaCl} 0.01 \mathrm{~g}, \mathrm{MgSO}_{4}$ $0.05 \mathrm{~g}, \mathrm{KNO}_{3} 0.2 \mathrm{~g}, \mathrm{NH}_{4} \mathrm{H}_{2} \mathrm{PO}_{4} 0.2 \mathrm{~g}$, peptone $1 \mathrm{~g}$ ). After two weeks of growth the mycelia were transferred in the form of agar tablets $1-2 \mathrm{~mm}$ thick $(\varnothing 0.5 \mathrm{~cm})$ to the surface of the soil in the petri dishes.

The clover rot fungus degenerated when continually cultured on artificial medium and had to be replaced twice with a more vigorous growth. In $1957-58 \mathrm{a}$ single-spore strain isolated at Viik was used, in 1959-60 a saltant of this strain was used, and in the years 1961 - 63 the fungus employed had been isolated in the autumn of 1960 from mycelia growing in an infected red clover plant in the field. During several years a sporadic decline in growth and also in the infective capacity of the clover rot fungal mycelia was observed. No reason for this could be found.

\section{Counts of microorganisms in the soil samples}

Directly before the antagonistic effectivity of the soil was determined, microbe counts were made of the soil samples. These counts were made by means of the dish dilution method (14), which is based on the development of living cells into colonies when growing on artificial media. The substrate used was soil extract agar prepared in the following manner: The soil extract consisted of soil and water in a ratio of 1:1 which was autoclaved for $30 \mathrm{~min}$; a small amount of $\mathrm{CaCO}_{3}$ was added and mixed; the solution was clarified by centrifuging and water was added to the original volume. The final agar medium consisted of $1000 \mathrm{~g}$ soil extract, $0.2 \mathrm{~g} \mathrm{~K}_{2} \mathrm{HPO}_{4}, 15 \mathrm{~g}$ agar; $\mathrm{pH}$ adjusted to about 6.0 with $\mathrm{NaOH}$. Since the substrate was soil extract, the colonies consisted principally of native (autoctonic) soil microorganisms (14). Before the counting was undertaken, the soil samples were diluted by adding $1 \mathrm{~g}$ soil to $99 \mathrm{ml} 0.05 \%$ peptone solution, which was further diluted (1:10). The most suitable dilution proved to be $1: 100000$. An 1-ml portion of it was added to a petri dish of liquid soil extract agar $\left(+45^{\circ} \mathrm{C}\right)$. The dishes $(2$ replicates per the soil sample) were held for 14 days at a temperature of about $+20^{\circ} \mathrm{C}$, after which the number of colonies was visually counted. Among the various microorganisms in the soil samples, the bacteria proper comprised about $82-93 \%$, the actinomycetes about $1-6 \%$ and the fungi about $5-16 \%$.

Correlation calculations for the trial results were performed according to MUDRA (15). In the outdoor trials determinations were made of the 
Table 1. Infection of red clover seedlings by $S$. trifoliorum in sterilized and u $\mathrm{n}$ te rilized soil samples.

\begin{tabular}{|c|c|c|c|c|c|c|}
\hline \multirow[t]{2}{*}{ Year } & \multirow[t]{2}{*}{ Soil sample } & \multicolumn{2}{|c|}{$\begin{array}{l}\% \text { of petri dishes } \\
\text { with infected } \\
\text { seedlings }\end{array}$} & \multicolumn{2}{|c|}{$\begin{array}{l}\text { Total no. } \\
\text { of } \\
\text { dishes }\end{array}$} & \multirow[t]{2}{*}{$\begin{array}{r}\text { Trial } \\
\text { period }\end{array}$} \\
\hline & & $\begin{array}{c}\text { Sterilized } \\
\text { soil }\end{array}$ & $\begin{array}{l}\text { Unsteri- } \\
\text { lized soil }\end{array}$ & $\begin{array}{c}\text { Sterilized } \\
\text { soil }\end{array}$ & $\begin{array}{l}\text { Unsteri- } \\
\text { lized soil }\end{array}$ & \\
\hline 1957 & $\begin{array}{l}\text { A. THERMOSTAT }\left(7-10^{\circ} \mathrm{C}\right) \\
\text { Fallow }\end{array}$ & 100 & 39 & 93 & 186 & 17. $4 .-13.12$. \\
\hline 1958 & Winter rye field & 99 & 57 & 138 & 276 & 14. 4. -10.12 . \\
\hline \multirow[t]{2}{*}{1959} & Fallow & 100 & 45 & 189 & 378 & 2. 4. -17.12 . \\
\hline & Clover field (year of sowing) & 99 & 38 & 189 & 378 & 2. 4. -17.12 . \\
\hline \multirow[t]{3}{*}{1960} & Fallow & 100 & 22 & 135 & 270 & 21. 4. -20.12 . \\
\hline & Clover field (1st year) & 98 & 23 & 135 & 270 & 21. 4. -20.12 . \\
\hline & Clover field (year of sowing) & 99 & 20 & 126 & 252 & 29. 4. -20.12 . \\
\hline \multirow[t]{8}{*}{1961} & Fallow & 91 & 15 & 90 & 150 & 17. 4. - 9. 12. \\
\hline & Clover field (1st year) & 88 & 15 & 90 & 150 & 17. $4 .-9.12$. \\
\hline & Clover field (year of sowing) & 86 & 6 & 90 & 150 & 17. 4. - 9. 12. \\
\hline & Average & 97 & 31 & Total 1275 & Total 2460 & \\
\hline & Av. temp. during 4-day period & & & & & \\
\hline & $\begin{array}{l}\text { before start of trial: } \\
<10^{\circ} \mathrm{C}\end{array}$ & 99 & 32 & 720 & 1392 & \\
\hline & $10^{\circ} \mathrm{C}<$ & 95 & 30 & 555 & 1068 & \\
\hline & B. OUTDOORS & & & & & \\
\hline \multirow[t]{3}{*}{1961} & Fallow & 98 & 24 & 84 & 140 & 17. 4. -22.11 . \\
\hline & Clover field (1st year) & 87 & 27 & 84 & 140 & 17. $4 .-22.11$. \\
\hline & Clover field (year of sowing) & 86 & 26 & 84 & 140 & 17. 4. -22.11 . \\
\hline \multirow[t]{3}{*}{1962} & Fallow & 100 & 29 & 96 & 192 & 17. 4. -28.11 . \\
\hline & Limed fallow & 78 & 6 & 93 & 186 & 30. 4. -28.11 . \\
\hline & Clover field (1st year) & 99 & 22 & 96 & 192 & 17. 4. -28.11 . \\
\hline \multirow[t]{8}{*}{1963} & Fallow & 90 & 33 & 72 & 144 & $22.4 .-7.11$. \\
\hline & Limed fallow & 79 & 15 & 72 & 144 & $22.4 .-7.11$. \\
\hline & Clover field (1st year) & 92 & 29 & 72 & 144 & $22.4 .-7.11$ \\
\hline & Limed clover field (1st year) & 85 & 3 & 72 & 144 & $22.4 .-7.11$. \\
\hline & Average & 90 & 21 & Total 825 & Total 1566 & \\
\hline & $\begin{array}{l}\text { Av. temp. during 2-week trial } \\
\text { period: }\end{array}$ & & & & & \\
\hline & $<10^{\circ} \mathrm{C}$ & 99 & 44 & 402 & 759 & \\
\hline & $10^{\circ} \mathrm{C}<$ & 81 & 7 & 423 & 807 & \\
\hline
\end{tabular}

correlation between the infection of clover by $S$. trifoliorum (scale $0-6 ; 6=$ infection in each of the 6 replicate dishes; in 1961 the scale was $0-5)$, the average temperature during the 2-week trial period, and the number of microorganisms in the soil at the beginning of the trial. In the thermostat trials $\left(7-10^{\circ} \mathrm{C}\right)$ the correlation was determined between the extent of infection by S. trifoliorum and the number of microorganisms in the soil at the start of the trial. 


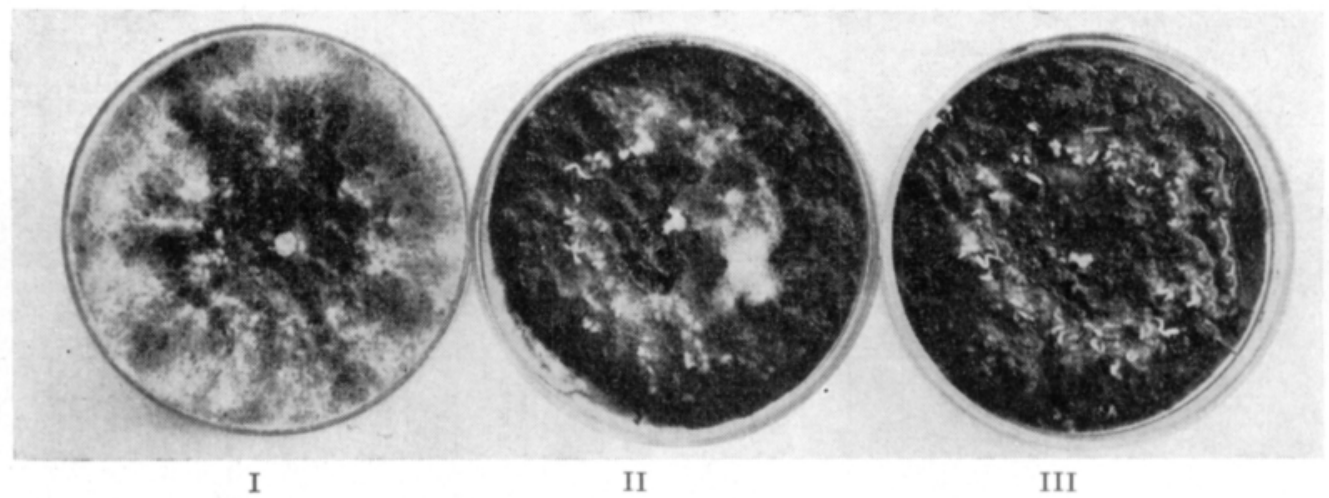

Fig. 2. Infection of red clover seedlings by $S$. $t r i$ fol $i$ or $u m$ in the soil samples. In the sterilized sample (I) the fungus has completely destroyed the plants, In one of the unsterilized samples (II) tehere are mycelia of both S. trifolior $m$ and $M u c o r$, in the other (III) only $M u$ cor.

Table 2. Infection of red clover seedlings by $S$. trifoliorum in $\mathrm{th}$ e r m o s t a t trials $\left(7-10^{\circ} \mathrm{C}\right)$. Results grouped according to average temperatures during 4-day periods before start of trial.

\begin{tabular}{|c|c|c|c|c|c|c|c|c|c|c|c|c|c|c|c|}
\hline \multirow{4}{*}{ Year } & \multirow{4}{*}{$\begin{array}{c}\text { Source of soil sample } \\
\text { (taken in April-De- } \\
\text { cember) }\end{array}$} & \multicolumn{14}{|c|}{$\%$ of petri dishes showing clover infection } \\
\hline & & \multicolumn{4}{|c|}{$0-5.0^{\circ} \mathrm{C}$} & \multicolumn{4}{|c|}{$5.1-10.0^{\circ} \mathrm{C}$} & \multirow{2}{*}{\multicolumn{2}{|c|}{$\begin{array}{c}10.1-15.0^{\circ} \mathrm{C} \\
\text { Summer }\end{array}$}} & \multirow{2}{*}{\multicolumn{2}{|c|}{$\begin{array}{c}15.1-20.0^{\circ} \mathrm{C} \\
\text { Summer }\end{array}$}} & \multirow{2}{*}{\multicolumn{2}{|c|}{$\begin{array}{l}20.1^{\circ} \mathrm{C}< \\
\text { Summer }\end{array}$}} \\
\hline & & \multicolumn{2}{|c|}{ Spring } & \multicolumn{2}{|c|}{ Autumn } & \multicolumn{2}{|c|}{ Spring } & \multicolumn{2}{|c|}{ Autumn } & & & & & & \\
\hline & & $\%$ & 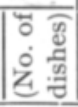 & $\%$ & 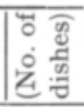 & $\%$ & 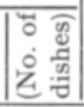 & $\%$ & 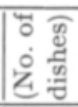 & $\%$ & 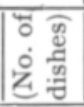 & $\%$ & 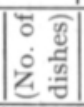 & $\%$ & 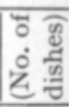 \\
\hline 1957 & Fallow & 38 & $(24)$ & 48 & (48) & 67 & (24) & 6 & (18) & 33 & (66) & 17 & (6) & & \\
\hline 1958 & Winter rye fiel & 71 & $(48)$ & 83 & (54) & 63 & (24) & 46 & $(48)$ & 4 & (72) & 25 & $(24)$ & 0 & (6) \\
\hline 1959 & Fallow & 67 & $(42)$ & 33 & $(120)$ & 77 & $(30)$ & 28 & (36) & 65 & $(60)$ & 32 & $(72)$ & 33 & (18) \\
\hline & $\begin{array}{l}\text { Clover field (year of } \\
\text { sowing) }\end{array}$ & 64 & $(42)$ & 13 & $(120)$ & 80 & $(30)$ & 25 & (36) & 62 & $(60)$ & 40 & (72) & 22 & (18) \\
\hline 1960 & Fallow & 42 & $(24)$ & 11 & $(66)$ & 17 & (6) & 19 & (36) & 19 & (54) & 28 & $(72)$ & 42 & (12) \\
\hline & Clover field (1st year) & 8 & $(24)$ & 8 & (66) & 50 & (6) & 31 & (36) & 33 & (54) & 43 & (72) & 8 & (12) \\
\hline & $\begin{array}{l}\text { Clover field (year of } \\
\text { sowing) }\end{array}$ & 8 & (12) & 6 & (66) & & & 1 s & (36) & 22 & (54) & 35 & (72) & 8 & (12) \\
\hline 1961 & Fallow & 0 & (10) & 40 & (25) & 4 & (25) & 37 & (30) & 0 & (15) & 0 & $(40)$ & 20 & (5) \\
\hline & Clover field (1st year) & 0 & (10) & 48 & (25) & 12 & $(25)$ & 27 & (30) & 0 & (15) & 0 & (40) & 0 & (5) \\
\hline & $\begin{array}{c}\text { Clover field (year of } \\
\text { sowing) }\end{array}$ & 0 & $(\mathbf{1 0})$ & 20 & (25) & 4 & (25) & 10 & $(30)$ & 0 & (15) & 0 & (40) & 0 & (5) \\
\hline & $\begin{array}{l}\text { Average } \\
\text { (Total) }\end{array}$ & 45 & (246) & 27 & (615) & 45 & (195) & 26 & (336) & 37 & $(465)$ & 26 & $(510)$ & 19 & (93) \\
\hline
\end{tabular}

Results

Sclerotinia trifoliorum grew well in the soil samples which had been s t e r i l i ze d. In some cases it caused infection of clover in all of the petri dishes (Table 1).

On the other hand, in the unsterilized soil samples the infection of clover caused by $S$. trifoliorum varied considerably in the different years (Table 1) 
Table 3. Infection of red clover seedlings by $S$. trifoliorum in petri dish trials performed o u t d o o r s . Results grouped according to average temperatures during the 2-week trial periods.

\begin{tabular}{|c|c|c|c|c|c|c|c|c|c|c|c|c|}
\hline \multirow{4}{*}{$\begin{array}{c}\text { Source of soil sample } \\
\text { (taken in April-December) }\end{array}$} & \multicolumn{12}{|c|}{$\%$ of petri dishes showing clover infection at different temperatures } \\
\hline & \multirow{2}{*}{\multicolumn{2}{|c|}{$\begin{array}{l}0-5.0^{\circ} \mathrm{C} \\
\text { Autumn }\end{array}$}} & \multicolumn{4}{|c|}{$5.1-10.0^{\circ} \mathrm{C}$} & \multirow{2}{*}{\multicolumn{2}{|c|}{$\begin{array}{l}10.1-15.0^{\circ} \mathrm{C} \\
\text { Summer }\end{array}$}} & \multirow{2}{*}{\multicolumn{2}{|c|}{$\begin{array}{l}15.1-20.0^{\circ} \mathrm{C} \\
\text { Summer }\end{array}$}} & \multirow{2}{*}{\multicolumn{2}{|c|}{$\begin{array}{l}20.1 / \mathrm{C}< \\
\text { Summer }\end{array}$}} \\
\hline & & & \multicolumn{2}{|c|}{ Spring } & \multicolumn{2}{|c|}{ Autumn } & & & & & & \\
\hline & $\%$ & 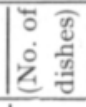 & $\%$ & 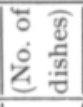 & $\%$ & 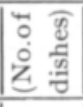 & $\%$ & 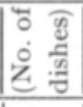 & $\%$ & 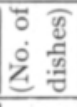 & $\%$ & 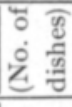 \\
\hline Fallow & 60 & (20) & 16 & (25) & 53 & $(30)$ & 5 & (20) & 0 & $(40)$ & 0 & (5) \\
\hline Clover field (1st year) & 55 & (20) & 36 & (25) & 47 & $(30)$ & 15 & (20) & 3 & $(40)$ & 0 & (5) \\
\hline Clocer field (year of sowing) & 65 & (20) & 24 & (25) & 57 & $(30)$ & 5 & (20) & 0 & $(40)$ & 0 & (5) \\
\hline Fallow & 61 & (36) & 57 & $(30)$ & 10 & $(42)$ & 14 & (72) & 17 & (12) & & \\
\hline Limed fallow & 25 & $(36)$ & 13 & (24) & 0 & $(42)$ & 0 & (72) & 0 & (12) & & \\
\hline Clover field (1st year) & 47 & (36) & 60 & (30) & 5 & $(42)$ & 8 & (72) & 0 & (12) & & \\
\hline Fallow & 75 & (18) & 58 & (18) & 44 & $(18)$ & 33 & (42) & 2 & (48) & & \\
\hline Limed fallow & 42 & (18) & 25 & (18) & 17 & (18) & 12 & $(42)$ & 0 & (48) & & \\
\hline Clover field (1st year) & 71 & (18) & 67 & (18) & 56 & (18) & 17 & (42) & 0 & $(48)$ & & \\
\hline Limed clover field (1st year) & 17 & (18) & 0 & (18) & 6 & $(18)$ & 0 & $(42)$ & 0 & $(48)$ & & \\
\hline $\begin{array}{r}\text { Average } \\
\text { (Total) }\end{array}$ & 55 & $(240)$ & 32 & $(231)$ & 26 & $(288)$ & 9 & (444) & 1 & (348) & 0 & (15) \\
\hline
\end{tabular}

No. of micro-organisms in millions per Ig soil

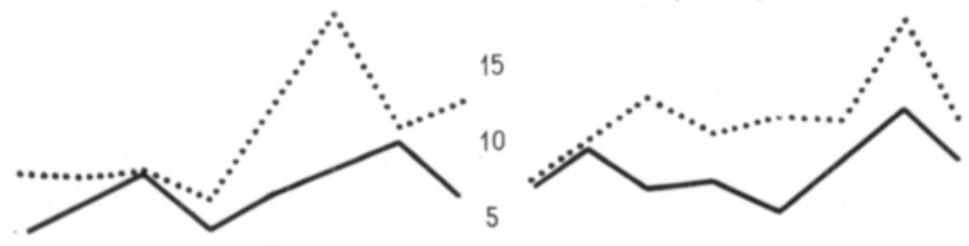

Percentage of clover dishes infekted

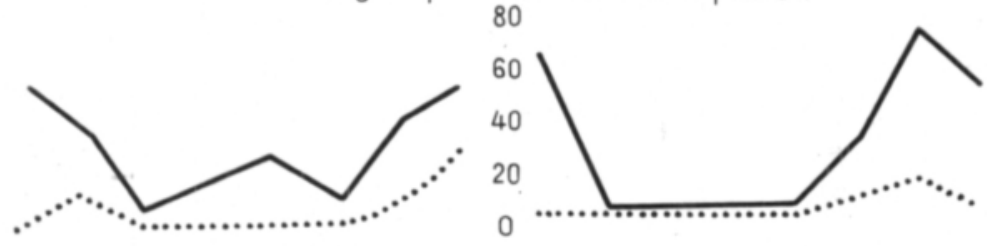
$\begin{array}{llllllllllllllll}I V & V & V I & \text { VII } & \text { VIII } & I X & X & X I & I V & V & \text { VI } & \text { VII } & \text { VIII } & I X & X & X I\end{array}$ $1962 \quad 1963$

1962

1963

Fallow ( $p H$ 5.4-5.8)

Clover field ( $p H$ 5.6-6.3)

Limed fallow $(p H 7.3-8.0) \ldots \ldots \ldots \ldots \ldots \ldots$. Limed clover field $(p H 6.3-7.5)$

Fig. 3. The number of soil microorganisms as well as the percentage of infection of clover in petri dishes by $S$. trifolior $u m$ in soil samples taken from limed and unlimed fields between April and November (total number of dishes about 190 in 1962, 144 in 1963; cf. Fig. 4). 
Table 4. Numbers of microorganisms in soil samples taken in April-December. Results grouped according to average temperatures during the 4-day periods before the counts were made. (The figures in brackets indicate the numbers of soil samples counted).

\begin{tabular}{|c|c|c|c|c|c|c|c|c|c|}
\hline \multirow{3}{*}{ Year } & \multirow{3}{*}{$\begin{array}{l}\text { Source of soil } \\
\text { sample }\end{array}$} & \multicolumn{8}{|c|}{ No. of microorganisms (in millions per $1 \mathrm{~g}$ soil) } \\
\hline & & \multicolumn{2}{|c|}{$0-5.0^{\circ} \mathrm{C}$} & \multicolumn{2}{|c|}{$5.1-10.0^{\circ} \mathrm{C}$} & \multirow{2}{*}{$\begin{array}{r}10 .-15.0^{\circ} \mathrm{C} \\
\text { Summer }\end{array}$} & \multirow{2}{*}{$\begin{array}{l}15.1-20.0^{\circ} \mathrm{C} \\
\text { Summer }\end{array}$} & \multirow{2}{*}{$\begin{array}{l}20.1^{\circ} \mathrm{C}< \\
\text { Summer }\end{array}$} & \multirow{2}{*}{$\begin{array}{c}0-21^{\circ} \mathrm{C} \\
\text { Whole tris } \\
\text { period }\end{array}$} \\
\hline & & Spring | & Autumn & Spring & Autumn & & & & \\
\hline 1958 & Winter rye field & $2.3 \quad(8)$ & $16.2 \quad(9)$ & $10.7 \quad$ (4) & $18.0 \quad(8)$ & $12.4(12)$ & $7.7 \quad$ (4) & $36.0 \quad(1)$ & $12.3(46)$ \\
\hline \multirow[t]{2}{*}{1959} & Fallow & $6.3 \quad(7)$ & $7.0(20)$ & $7.0 \quad(5)$ & $\begin{array}{ll}7.2 & (6)\end{array}$ & $6.5(10)$ & $6.7(12)$ & $6.6 \quad(3)$ & $6.8(63)$ \\
\hline & $\begin{array}{l}\text { Clover field (year of } \\
\text { sowing) }\end{array}$ & $6.5 \quad(7)$ & $12.6 \quad(20)$ & $6.8 \quad(5)$ & $15.0 \quad(6)$ & $8.8(10)$ & $11.3(12)$ & $8.7 \quad(3)$ & $10.6(63)$ \\
\hline \multirow[t]{3}{*}{1960} & Fallow & $8.8(4)$ & 19.1 (11) & $6.9 \quad(1)$ & $15.7 \quad(6)$ & $15.9 \quad(9)$ & $15.4(12)$ & $16.2 \quad(2)$ & $15.7(45)$ \\
\hline & year) & $8.3 \quad(4)$ & $14.3(11)$ & $7.1 \quad(1)$ & $14.3 \quad(6)$ & $13.4 \quad(9)$ & $12.3(12)$ & $9.9 \quad(2)$ & $12.7(45)$ \\
\hline & $\begin{array}{l}\text { Clover field (year of } \\
\text { sowing) }\end{array}$ & $11.4 \quad(2)$ & $16.5(11)$ & & $15.7 \quad(6)$ & $17.1 \quad(9)$ & 13.8 (12) & $9.7 \quad(2)$ & $15.2(42)$ \\
\hline \multirow[t]{3}{*}{1961} & $\begin{array}{l}\text { Fallow } \\
\text { Clover field (1st }\end{array}$ & $13.5 \quad(2)$ & & $13.6 \quad(5)$ & $8.6 \quad(6)$ & $8.9 \quad(3)$ & $11.6 \quad(8)$ & $11.9 \quad(1)$ & $10.4(30)$ \\
\hline & year) & $12.2 \quad(2)$ & $7.1 \quad(5)$ & $19.4 \quad(5)$ & $8.2 \quad(6)$ & $13.0 \quad(3)$ & $12.0 \quad(8)$ & $11.4 \quad(1)$ & $11.7(30)$ \\
\hline & $\begin{array}{l}\text { Clover fleld (year of } \\
\text { sowing) }\end{array}$ & $10.2 \quad(2)$ & $6.8 \quad(5)$ & $14.0 \quad(5)$ & $14.9 \quad(6)$ & $8.5 \quad(3)$ & $9.1 \quad(8)$ & $\begin{array}{ll}7.1 & (1)\end{array}$ & $11.3(30)$ \\
\hline \multirow[t]{3}{*}{1962} & Fallow & $5.3 \quad(3)$ & $\begin{array}{ll}7.8 \quad(4) \\
\end{array}$ & $6.0 \quad(2)$ & $9.4 \quad(7)$ & $7.6(12)$ & $4.8 \quad(4)$ & & $7.4(32)$ \\
\hline & Limed fallow & $\begin{array}{ll}7.7 & (2)\end{array}$ & $12.1 \quad(4)$ & $9.3 \quad(2)$ & $13.5 \quad(7)$ & $11.5 \quad(12)$ & $5.9 \quad(4)$ & & $10.9(31)$ \\
\hline & ye & $5.7 \quad(3)$ & $10.6 \quad(4)$ & $10.8 \quad(2)$ & $15.1 \quad(7)$ & $10.7(12)$ & $8.8 \quad(4)$ & & 11.0 \\
\hline \multirow[t]{5}{*}{1963} & Fallow & & $8.8 \quad(3)$ & $5.9 \quad(3)$ & $10.6 \quad(3)$ & $6.4 \quad(7)$ & $5.6 \quad(8)$ & & $6.9(24)$ \\
\hline & Limed fallow & & $13.0 \quad(3)$ & $6.9 \quad(3)$ & $13.2 \quad(3)$ & $8.3 \quad(7)$ & $9.4 \quad(8)$ & & $9.7 \quad(24)$ \\
\hline & $\begin{array}{l}\text { Clover field (1st } \\
\text { year) }\end{array}$ & & $10.9 \quad(3)$ & $8.5 \quad(3)$ & $12.5 \quad(3)$ & $9.0 \quad(7)$ & $6.9 \quad(8)$ & & 8.9 (24) \\
\hline & $\begin{array}{l}\text { Limed clover field } \\
\quad \text { (1st year) }\end{array}$ & & $|15.0 \quad(3)|$ & $\begin{array}{ll}7.8 & (3)\end{array}$ & $18.3 \quad(3)$ & $10.7 \quad(7)$ & $11.8 \quad(8)$ & & $12.2(24)$ \\
\hline & $\begin{array}{r}\text { Average } \\
\text { (Total) }\end{array}$ & $\begin{array}{ll}6.9 & \\
& (46)\end{array}$ & $\mid \begin{array}{l}12.0 \\
(121)\end{array}$ & $\begin{array}{ll}10.2 & \\
& (49)\end{array}$ & $\begin{array}{ll}13.2 & \\
& (89)\end{array}$ & $\begin{array}{l}10.6 \\
(132)\end{array}$ & $\begin{array}{l}10.2 \\
(132)\end{array}$ & $\begin{array}{ll}11.5 & \\
& (16)\end{array}$ & $\begin{array}{l}11.0 \\
\\
(585)\end{array}$ \\
\hline
\end{tabular}

and at different times of the year (Fig. 4). In general, however, there were relatively small variations in infection between the soil samples taken at the same time from the various areas of the field cultivated in different ways. Nevertheless, in some autumns infection was less marked in the samples taken from clover fields than in those from fallow (Fig. 4). Furthermore, liming appreciably reduced the extent of infection (Table 1; Figs. 3 and 4).

In the outdoor trials, clover was more severely infected in the spring and autumn than in the summer; often it did not become infected at all in the summer (Fig. 4; Table 3). The maximum infection occurred late in the autumn, at a time when the temperature was lowest $\left(0-5^{\circ} \mathrm{C}\right)($ Table 3$)$. In the thermostat trials $\left(7-10^{\circ} \mathrm{C}\right)$ the clover rot fungus generally caused considerable infection also in the soil samples taken in the summer (Fig. 4; Table 2). A statistically significant negative correlation occurred between the infection of clover by $S$. trifoliorum and the temperature during the 2-week trial period (Table 5, B). 
Table 5. The effect of the number of soil microorganisms and the temperature on the infection of red clover by $S$. trifoliorum, as determined by correlation calculations. (The infection was judged on a scale of $0-6$ in which $6=$ plants in all the 6 replicate dishes were infected; in 1961 the scale was $0-5$ ).

\begin{tabular}{|c|c|c|c|c|}
\hline \multirow[b]{2}{*}{ Year } & \multirow[b]{2}{*}{$\begin{array}{l}\text { Soil sample taken in } \\
\text { April-December }\end{array}$} & \multirow[b]{2}{*}{$\begin{array}{l}\text { No. of } \\
\text { trials }\end{array}$} & \multicolumn{2}{|c|}{ Regression coefficients } \\
\hline & & & $\begin{array}{c}\mathrm{b}_{1} \\
\text { No. of microbes } \\
\text { start of trial } \\
\text { (mill. per l g soil) }\end{array}$ & $\begin{array}{l}\mathrm{b}_{2} \\
\text { Av. temp. during } \\
\text { 2-week trial } \\
\left({ }^{\circ} \mathrm{C}\right)\end{array}$ \\
\hline & A. THERMOSTAT $\left(7-10^{\circ} \mathrm{C}\right)$ & & & \\
\hline 1957 & Fallow & 31 & - & \\
\hline 1958 & Winter rye field & 46 & -0.05 & \\
\hline 1959 & Fallow & 63 & -0.04 & \\
\hline & Clover field (year of sowing) & 63 & $-0.23^{* * *}$ & \\
\hline 1960 & Fallow & 45 & -0.06 & \\
\hline & Clover field (1st year) & 45 & -0.02 & \\
\hline & $\quad$ (year of sowing) & 42 & -0.08 & \\
\hline 1961 & Fallow & 30 & -0.10 & \\
\hline & Clover field (1st year) & 30 & -0.05 & \\
\hline & B. OUTDOORS & 30 & -0.04 & \\
\hline 1961 & Fallow & 28 & -0.12 & $-0.17 * *$ \\
\hline & Clover field (1st year) & 28 & +0.01 & $-0.19 * * *$ \\
\hline & $\quad$ (year of sowing) & 28 & +0.03 & $-0.21 * * *$ \\
\hline 1962 & Fallow & 32 & -0.14 & $-0.22 * *$ \\
\hline & Limed fallow & 31 & -0.04 & $-0.11 * *$ \\
\hline & Clover field (1st year) & 32 & -0.09 & $-0.20^{* *}$ \\
\hline 1963 & Fallow & 24 & +0.28 & $-0.25^{* *}$ \\
\hline & Limed fallow & 24 & -0.05 & $-0.18^{* * *}$ \\
\hline & Clover field (1st year) & 24 & $-0.08^{* *}$ & $-0.48^{* * *}$ \\
\hline & Limed clover field (1st year) & 24 & +0.03 & $-0.05^{*}$ \\
\hline
\end{tabular}

In the thermostat trials $\left(7-10^{\circ} \mathrm{C}\right)($ Table 2$)$, as well as in the outdoor trials when the temperature was $5-10^{\circ} \mathrm{C}$ (Table 3 ), S. trifoliorum generally caused more severe infection of clover in the spring than in the autumn. In 1961, however, infection was much more severe in the autumn than in the spring (Tables 2 and 3).

As a rule, the maximum numbers of microorganisms in the soil were found in the autumn and the minimum numbers in the spring (Table 4). In 1961, however, they were more numerous in the spring. Larger amounts of soil microbes were often encountered in the samples taken from the clover field than in those from the fallowed area; this was especially evident in the autumn. Liming resulted in an increase in the numbers of microorganisms (Fig. 3).

In the thermostat trials $\left(7-10^{\circ} \mathrm{C}\right)$ there was always a negative correlation between the infection of the clover plants and the numbers of microorganisms in the soil at the onset of the trial. However, only in one case was this correlation statistically significant (Table 5, A). In the outdoor trials the correlation between these factors varied from year to year (Table 5, B). Taking into account, however, 


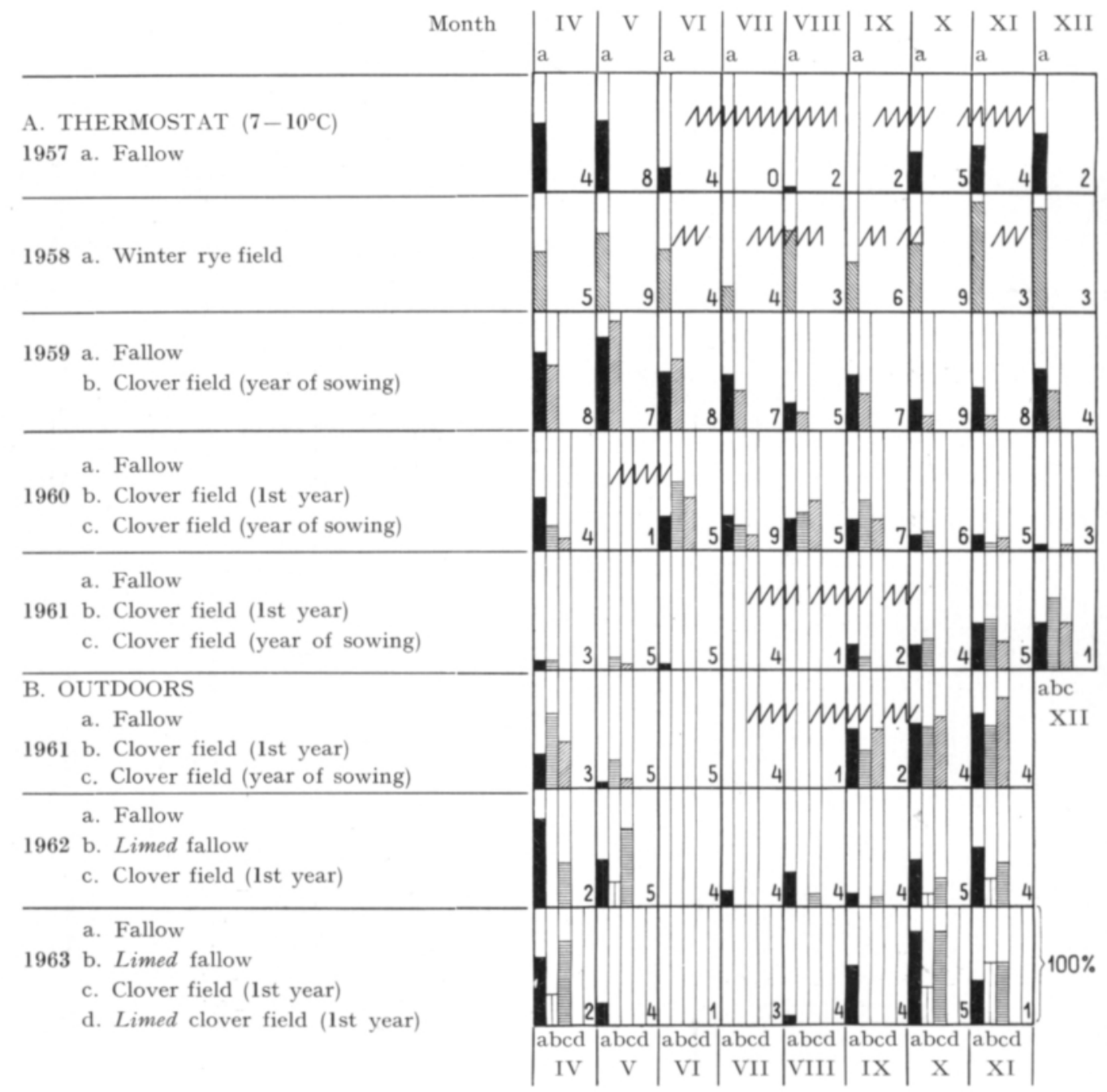

Fig. 4. The infection of red clover seedlings by $S$, trifolior $u m$ in soil samples in different months. The amount of infection is denoted by the columns whose height indicates the percentage of petri dishes in which the seedlings were infected.

The number of trials in each month is shown by the numerals; in each trial there were 6 petri dishes $(5$ in 1961). WWWWW = the mycelia of S. trifoliorum used for inoculating the soil samples grew poorly (cf. p. 122)

only those results obtained at the temperature range $5-10^{\circ} \mathrm{C}$, it can be seen that when there were small numbers of microorganisms in the soil, S. trifoliorum generally grew better than when the numbers were large (Fig. 6).

\section{Discussion}

In general, clover plants become infected with the clover rot fungus (Sclerotinia trifoliorum ) in the autumn. The damage may continue during the winter and spring, but in the middle of the summer the disease generally does not occur. This 
Month

I.ong-term temperature and precipitation values at Helsinki 1921 $-1950$
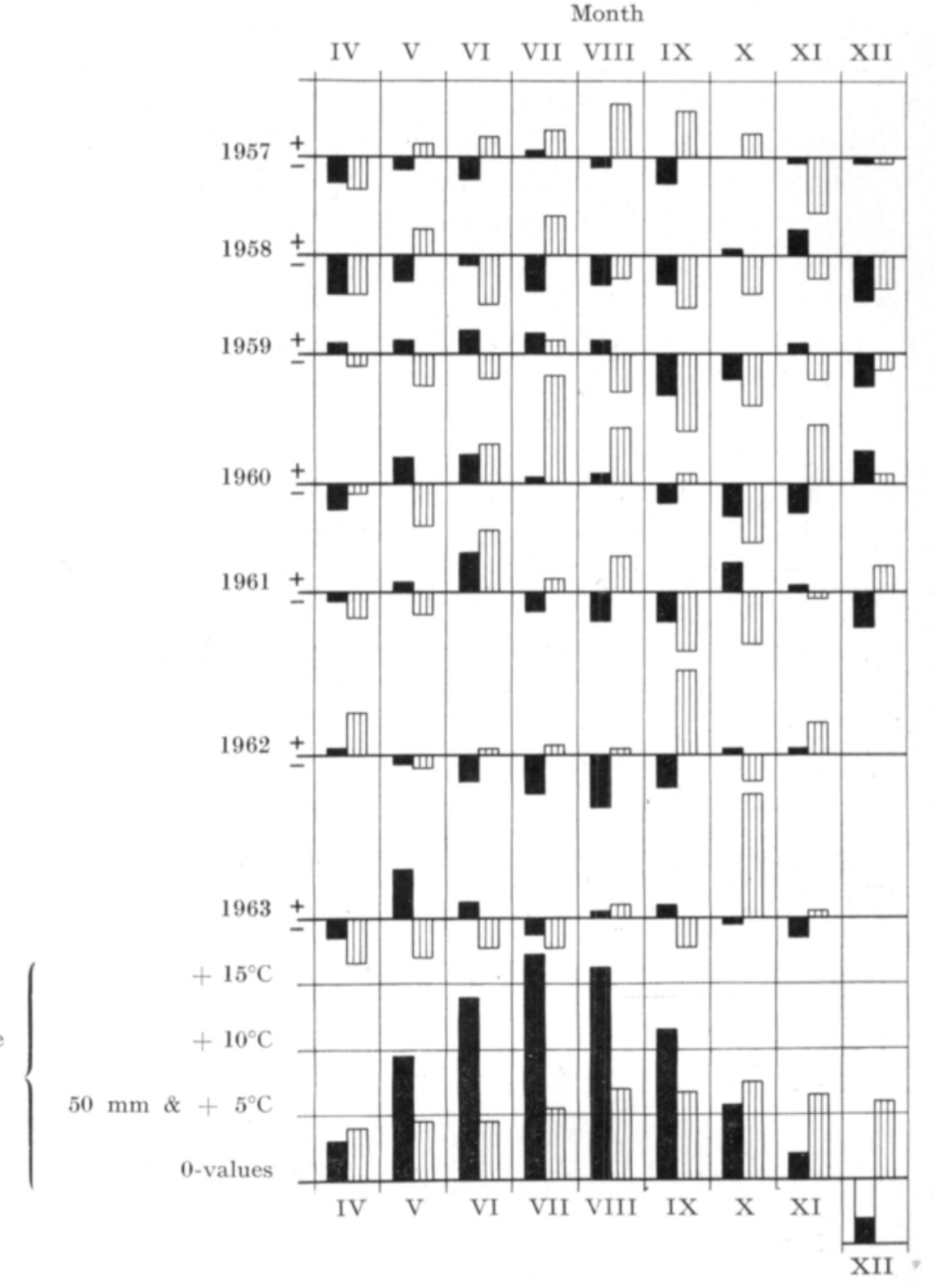

Fig. 5. Long-term mean temperatures December 1921-1950

$\left.{ }^{\circ} \mathrm{C}\right)$ and precipitation ( $\mathrm{mm}$ ) at Helsinki in the months Aprilas well as their deviations at Viik 1957-1963

has been attributed mainly to the fact that the dry conditions usually accompanying the high temperatures of the summer check the growth of the clover rot fungus $(2,3,7,13,17,18,19,25,29)$. However, in the present trials, the infection was generally lightest in the middle of the summer also when the clover was grown in petri dishes where the soil was constantly moist. This is most clearly seen in the outdoor trials (Fig. 4, B) performed during the warmest period of the summer (Fig. 5) and indicates that the temperature had a preventive effect on clover rot infection especially during the actual time of the trial (Table 3). In checking infection the 
temperature scarcely played a direct part, since it is known that the mycelia of Sclerotinia trifoliorum can grow throughout a temperature range of $0-33^{\circ} \mathrm{C}(16)$, the optimum being $13-20^{\circ} \mathrm{C}(7,11,16,18)$.

Autoclaving of the soil had a marked effect in increasing the amount of infection of the clover seedlings growing in it (Table 1). This may show that the microorganisms normally occurring in soil limited the extent of clover rot infection in unsterilized soil. The formation of mycelia from sclerotia on the surface of autoclaved soil is also very abundant (6). Furthermore, it is known that autoclaving changes the soil nutrients into a form readily utilizible by fungal organisms (30), but at present it is not known whether this could lead to an increase in clover rot infection.

The number of soil microorganisms was not found, however, to be greater during the warm part of the summer - when clover rot infection was slight (Table 3 ; Fig. 4, B) - than in the spring and autumn (Table 4; cf. 28). On the other hand, at relatively low temperatures $\left(5-10^{\circ} \mathrm{C}\right)$ the extent of infection decreased as the number of soil microbes increased (Table 5, A; Fig. 6). As a rule, there were less microbes in the soil in the spring than in the autumn (Table 4). Correspondingly, clover rot infection was usually (at $5-10^{\circ} \mathrm{C}$ temperatures) more severe in the spring than in the autumn (Tables 2, 3). In this case, accordingly, the number of microorganisms determined the antagonistic power of the soil. At other temperatures such a corre-

No. of microorganisms

(millions per $1 \mathrm{~g}$ soil)

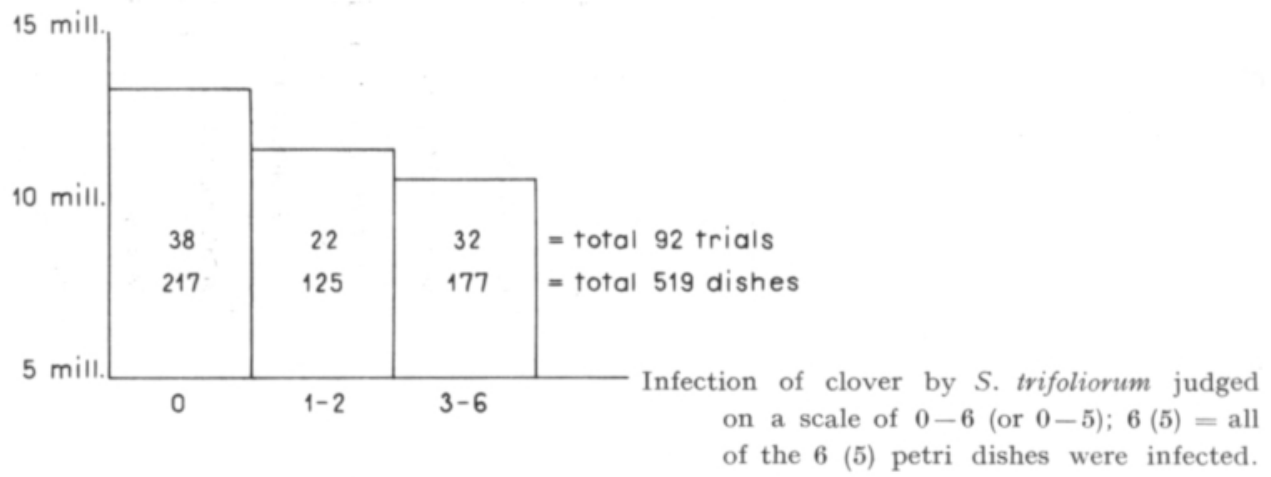

Fig. 6. The numbers of soil microorganisms and the amount of infection of red clover by $S$. $t r i f o l i o-$ $r u m$ in soil samples in trials performed outdoors at a temperature of $5-10^{\circ} \mathrm{C}$.

lation was not observed (Table 5, B), which suggests that the effect of soil microorganisms in hindering clover rot infection (Table 5, B) is mainly due to their antagonistic influence. As is generally known, a rise in temperature increases the rate of metabolism of microbes (26) as well as the formation of many antibiotic substances (cf. 12). On certain artificial media, the infection-checking effect of the soil microorganisms was also found to be enhanced by an increase in the temperature (Fig. 7). 

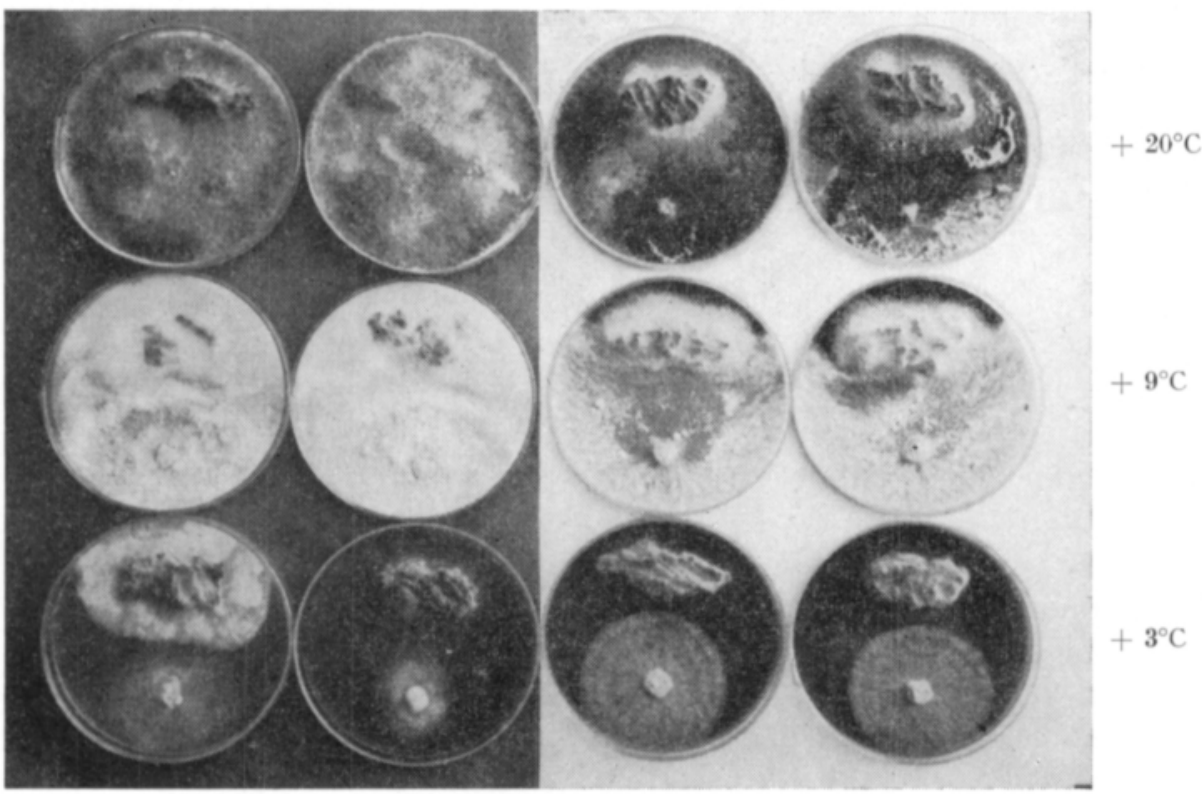

Fig. 7. The effect of a soil inoculum transferred to nutrient agar medium on the growth of S. $t r$ ifolio $r u m$ at different temperatures.

S. trifolior $u m$ was inoculated to the lower edge of the dish, the soil to the upper edge. The growth is 2 weeks old. The soil contained microorganisms such as $M u c o v, T r i c h o d e r m$ a and bacteria.

It is known $(10,16)$ that $S$. trifoliorum can grow in a wide range of $\mathrm{pH}$ concentrations, between 2.1 and 8.0 ; its optimum is $\mathrm{pH} 5.5-6.5$ (16). In the current trials, treating fields with lime - which raised the soil $\mathrm{pH}$ to the alkaline side — appreciably increased the number of microorganisms and at the same time reduced the amount of clover rot infection (Fig. 3). In earlier studies $(1,16,18,19)$ the soil reaction was not known to have influenced the occurrence of clover rot on the field. This was possibly due to the fact that the fungus spread in the form of spores directly on the leaves of the clover plants (cf. 9, 13, 25). In the present trials, on the other hand, the clover became infected from the mycelia growing in the soil; such mycelial infection may also take place under normal field conditions $(7,8,31)$.

The clover plants were less severely infected by the fungus in limed than in unlimed soil samples also in the cases when the soil was sterilized (Table 1). Likewise, the infection was somewhat weakened at high temperatures even in the sterilized samples (Table 1). This can be taken as being due to the fact that the autoclaving of the soil - although it killed the bacteria — did not completely destroy all the antibiotic substances in the soil. However, since the effect of soil sterilization in enhancing clover rot was even more distinct in the thermostat $\left(7-10^{\circ} \mathrm{C}\right)$ trials than in those performed outdoors under varying temperature conditions, it appears that also other factors did to some extent modify the results. In this case attention can 
be drawn to the fact that sometimes - due to unknown reasons - the mycelial growth of the fungus declined, a phenomen on which often occurred during the warm part of the summer (Fig. 4).

\section{Conclusions}

In the petri dish trials the mycelia of Sclerotinia trifoliorum in s t e rilize d soil samples generally infected clover quite readily. In u n t e rili z e d samples the infection was less severe and showed marked variations in different years and at different times of the year. In the outdoor trials clover became less infected in the middle of the summer than in the spring and autumn. On the other hand, in the thermostat trials, where the temperature was constantly $7-10^{\circ} \mathrm{C}$, the temperature at the time of taking the soil samples did not have a pronounced effect on the extent of clover infection.

Liming of the soil caused a marked decrease in the severity of clover rot infection. In some autumns clover plants growing in soil samples taken from fallow were more seriously infected than those growing in soil from a clover field. As a rule, however, there were only slight variations in the extent of infection in the soil samples taken at the same time from the various areas of the field cultivated in different ways.

In general, the highest numbers of microorganisms in the soil were found in the autumn and the lowest in the spring. In clover fields there were often more microorganisms - particularly in the autumn - than in fallow. Liming caused an increase in the numbers of soil microbes.

S. trifoliorum infected clover very severely at temperatures of $0-5^{\circ} \mathrm{C}$; in the range $5-21^{\circ} \mathrm{C}$ the infection grew generally milder the more the temperature was found to be rising. At temperatures of $5-10^{\circ} \mathrm{C}$ an increase in the numbers of soil microbes resulted in a decrease in the infection of the clover. Still higher temperatures, which did not increase the numbers of soil microorganisms, nevertheless enhanced the antagonistic power of the soil.

REFERENCES

(1) Behringer, P. 1963. Ein Beitrag zu Sicherheit des Rotklee-Anbaues, insbesondere durch Bekămpfung des Kleekrebses (Sclerotinia triflorum ErIKss.). Bayer. Landw. Jbuch 40: 643-670.

(2) Bingefors, S. 1951. Sambandet mellan väderleksförhållandena och omfattningen av klöverrötangreppen vid Ultuna under åren 1930-1950. Sver. Utsädesför. Tidskr. 61,3: 100-107.

(3) BJörLING, K. 1942. Undersökningar rörande klöverrötan II. Stat. växtskyddsanst. medd. 37: 1 -154 .

(4) Brian, P. W. 1949. The production of antibiotics by soil microorganisms. Chem. Ind., Lond. pp. $391-393$. 
(5) Brian, P. W. 1949. The production of antibiotics by microorganisms in relation to biological equilibria in soil. Symp. Soc. exp. Biol. 3: 357-372.

(6) Erviö, L-R. \& Нацкilahti, A-M. \& Poнјакаllio, O. 1964. The surviving in the soil of sclerotia of two Sclerotinia-species and their ability to form mycelia. Repr. from Advancing Frontiers of Plant Sci. 8: $121-134$.

(7) Frandsen , K. J. 1946. Studier over Sclerotinia trifoliorum Eriksson. 222 s. København.

(8) Halkilahti, A-M. 1962. The survival of sclerotinia of Sclerotinia trifoliorum ERIKss. on the soil and the occurrence of clover rot in various years. Maataloustiet. aikak. 34: 154-161.

(9) Justham, M. \& Ogilvie, L. 1950. Clover rot investigations. Ann. Appl. Biol. $37: 328$.

(10) Korvistoinen, P. \& Pohjakallio, O. 1959. On the antagonism between Sslerotinia trifoliorum Erikss. and Aerobacter aerogenes (Kruse) BeIJerink. Acta Agr. Scand, 9,2: 149-163.

(11) Kreitlow, K. W. \& Sprague, V. G. 1951. Effect of temperature on growth and pathogenity of Sclerotinia trifoliorum. Phytopath. XLI, 8: 752-757.

(12) KöнleR, H. 1956. Einführung in die Methoden der pflanzlichen Antibiotikaforschung. 351 s. Berlin.

(13) Loveless, A. R. 1951. Observations on the biology of clover rot. Ann. Appl. Biol. 38: 642-664.

(14) Mikrobiologian laboratorioharjoitukset. 1955. Jakso II a (Maan mikrobiologiaa) Helsingin yliopiston mikrobiologian laitos. Moniste. $39 \mathrm{~s}$. Helsinki.

(15) Mudra, A. 1958. Statistische Methoden für Landwirtschaftliche Versuche. $336 \mathrm{~s}$. Hamburg.

(16) PAPE, H. 1937. Beiträge zur Biologie und Bekämpfung des Kleekrebses (Sclerotinia trifoliorum Erikss.). Arb. Biol. Reichsanst. 22,2: 159-247.

(17) Ронјакаllı, O. 1939. Apilamädästä ja sen vastustamisesta. Ylipainos »Maa» n:o 2:sta v. 1939.

(18) - - 1939. Untersuchungen über den Kleekrebs und seinen Anteil am Verschwinden des Klees in Kleegrasgemischen. Pflanzenbau 16,4: 136-140 und 16,5: 201-205.

(19) - 1939. Kasvinjalostusbiologisia tutkimuksia apilamädästä. S. Tiedeak. esit. ja pöytäk. 1939, $115-128$.

(20) - - 1957. Untersuchungen über Antagonisten der Erreger von Pflanzenkrankheiten. Sond. abdr. Verh. IV Intern. Pfl.schutz-Kongr. Hamburg 1957,2 (Braunschweig 1960): $1541-$ 1543.

(21) - - \& Salonen, A. 1950. On the appearance and significance of fungi and bacteria antibiotically affecting the fungus Sclerotinia trifoliorum ERIKss. Maataloustiet. aikak. 22: $63-67$.

(22) - - \& SAlonen, A. \& LAAKKonen, E. 1949. Investigation into the Bacteria Antibiotically Affecting the fungus Sclerotinia trifoliorum ERIKSs. Physiol. Plant. 2: 312-322.

(23) - - \& SAlonen, A. \& Relander, E. 1953. Investigation into the micro-organisms limiting damage by the clover rot fungus. Acta Agr. Scand. III, I: 53-60.

(24) - - \& Salonen, A. \& Ruokola, A-L. \& Ікйнeimo, K. 1956. On a Mucous Mould Fungus, Acrostalagmus roseus Bainier, as Antagonist to some Plant Pathogens. Acta Agr. Scand. 6,2: $178-194$.

(25) RUDORF, W. 1937. Untersuchungen zur Züchtung von kleekrebsresistenten Kleearten und Luzerne. Zücht. 9, 10: 249-253.

(26) Russel, E. J. ref. Waksman, S. A. \& Starkey, R. L. 1950. The soil and the mikrobe. 260 p. New York.

(27) Waksman, S. A. 1945. Microbial antagonisms and antibiotic substances. 350 p. New York.

(28) Waksman, S. A. \& Starkey, R. L. 1950. The soil and the mikrobe. 260 p. New York.

(29) VAlle, O. 1930. Apilamädästä ja sen tuhoista. Suomen laiduntalous 2: 33-46.

(30) Wright, J. M. 1955. The production of antibiotics in soil. II. Production of griseofulvin by Penicillium nigrigans. Ann. Appl. Biol. 43,2: 288-296.

(31) Yьгмӓкі, A. 1956. Additional Experiments on the Chemical Control of Clover Rot. Valt. maatal. koet. julk. 148: $31-49$. 
MAAN PIENELIÖSTÖN MERKITYKSESTÄ APILAN SCLEROTINIA TRIFOLIORUM ERIKSS.INFEKTIOTA RAJOITTAVANA TEKIJÄNÄ VUODEN ERI AIKOINA

\author{
Anna-Marja Halkilahti \\ Helsingin yliopiston kasvipatologian laitos
}

Petrinmaljakokeissa Sclerotinia trifoliorumin rihmasto saastutti s te riloid u is s a maanäytteissä apilaa yleensä verraten hyvin. Steriloi mat to mis s a maanäytteissä sen saastutuskyky oli pienempi ja eri vuosina sekä eri vuodenaikoina varsin vaihteleva. Ulkona suoritetuissa kokeissa apila saastui lievemmin keskikesällä kuin keväällä ja syksyllä. Sen sijaan termostaattikokeissa, joissa lämpötila oli jatkuvasti $7-10^{\circ} \mathrm{C}$, ei maanäytteen ottamisajankohdan lämpötilalla ollut selvää vaikutusta apilan saastumiseen.

Kalkitus heikensi apilamätäsienen saastutuskykyä huomattavasti. Eräinä syksyinä apilamätäsieni saastutti ankarammin kesannosta kuin apilapellosta otetussa mullassa kasvanutta apilaa. Yleensä ei apilamätäsienen saastutuskyky kuitenkaan kovin paljon vaihdellut saman peltolohkon eri tavoin viljellyistä osista keskenään samaan aikaan otetuissa maanäytteissä.

Mikrobeja oli maassa yleensä eniten syksyllä ja vähiten keväällä. Apilapellossa oli mikrobeja usein, etenkin syksyisin, enemmän kuin kesantomaassa. Kalkitus lisäsi mikrobien määrää.

$S$. trifoliorum saastutti apilaa hyvin ankarasti $0-5{ }^{\circ} \mathrm{C}$ :n lämpötiloissa ja $5-21^{\circ} \mathrm{C}$ :n lämpötiloissa yleensă sitä lievemmin mitä korkeampi lämpötila oli. $5-10^{\circ} \mathrm{C}$ :n lämpötiloissa apilan saastuminen heikkeni maan mikrobiluvun noustessa. Korkeammat lämpötilat, jotka eivät suurentaneet mikrobien lukua maassa, lisäsivät kuitenkin maan antagonistista voimaa. 